\title{
Effects of gelatin and preparation methods on the quality and antioxidant of velvet tamarind (Dialium guineense) halal chewy product
}

\author{
${ }^{1,{ }^{*}}$ Cheadoloh, R., ${ }^{2}$ Waeno, M. and ${ }^{3}$ Asae, S. \\ ${ }^{1}$ Department of Food Science and Technology, Faculty of Science Technology and Agriculture, Yala \\ Rajabhat University, Yala 95000, Thailand \\ ${ }^{2}$ Faculty of liberal art and social science, Fatoni University, Yarang, Pattani 94160, Thailand \\ ${ }^{3}$ Faculty of Education, Fatoni University, Pattani 94160, Thailand
}

\begin{abstract}
Article history:
Received: 10 March 2021

Received in revised form: 15

April 2021

Accepted: 17 June 2021

Available Online: 26 January 2022
\end{abstract}

\section{Keywords:}

Chewy velvet tamarind,

Gelatin,

Panellists test,

Halal product,

Antioxidant

DOI:

https://doi.org/10.26656/fr.2017.6(1).095

\begin{abstract}
Presently, chewy food products are at risk of contamination of non-halal pork gelatin for Muslim consumers. Thus, the sensory study is vital to ensure that products using halal gelatin will have comparable quality. This work was aimed at studying the influence of the formulation and processing of sweet chewy products made from velvet tamarind (VT). The effects of gelatin content from 1.5 to $9 \%$ on sensory acceptance were examined. The results revealed that gelatin of $9 \%$ was the highest sensory score in all sensory aspects, which were statistically significant differences between the groups studied $(p \leq 0.05)$. It had an overall liking score of 7.23 (like moderately). A comparison study on sugar ratio and filtration process on physical-chemical properties and sensory acceptance was also conducted. Sensory testing showed that the VT solution content at UVT, ratio 1:1.74 gave the highest average preference score was different significantly from average $(p \leq 0.05)$. It had an overall liking score of 7.15 (like moderately). The products of best chewy VT found that the moisture content, $\mathrm{a}_{\mathrm{w}}$ and $\mathrm{pH}$ was $4.98 \%, 0.66$ and 3.65 , respectively. It was found that the extract contained a substantial amount of antioxidants in the form of vitamin $\mathrm{C}$ and phenolic compounds, where the $\mathrm{IC}_{50}$ was evaluated at $53.64 \mu \mathrm{g} / \mathrm{mL}$. Therefore, the quality of the halal sweet chewy products was found to be acceptable by the sensory evaluation of panel members.
\end{abstract}

\section{Introduction}

Nowadays, halal food products are important in driving the Thai economy (Reuters and Standard, 2018). According to the government's policy to promote Thailand to export halal products, the exportation ranked first with targeting the exporters of halal products worldwide within 2017. Nevertheless, the current ranking is 13 , with a total market value of more than 1.6 trillion US dollars among consumers around the world, which is more than 2000 million (Office of the Board of Investment, 2016). Next, it is Halal 4.0 that begins in 2017 until now, which the halal logo becomes the second brand for halal products and services. The certification also links with the Internet of Things (IoT), cloud, e-commerce, and others (Priyakorn, 2017). Food is a necessity of life that gives energy and nutrients for growth. For Muslim consumers, halal is an important aspect of food selection as it is one's part to obey religious obligations and commandments. The Muslim world is expected to experience a rapid population growth from 1.8 billion in 2012 to 2.2 billion in 2030 (Ruslan et al., 2018).

Chewy products are essentially composed of sugars (sucrose and glucose syrup), fat, textural agents emulsifier, colour, flavour, and acid. In sugar-free formulations, bulk sweeteners (polyols or sugar alcohols) can be used as sugar replacers, bringing technological benefits, particularly contributing mainly to the sweetness, bulk, and texture (Sadler and Stowell, 2012). The texture features of food may indicate its quality and greatly influence consumer acceptance and preference. The consistency and chewability of sugar-free chewy products are affected by the crystallisation properties of the polyols and their balance with the non-crystallisable phase of the product (Sentko and Willibald-Ettle, 2012). The physical or textural characteristics are also significantly influenced by the water content (Figiel and Tajner-Czopek, 2006), the textural agent, and the fat content and type. 
Velvet tamarind; VT (Dialium guineense) is an essential fruit in the three borders southern province of Thailand (Chedoloh and Chemalee, 2019). The VT trees can be found in Southern Thailand. People in Yala, Patani and Narathiwat province recognise them as Lukyee and Kerayee. It is a tree of an average height of about $30 \mathrm{~m}$ with a densely leafy crown, and smooth greyish bark. Leaves are hairy, and the flowers are usually whitish while the fruits are less circular and flattened. The pulp of the fruit is edible and sweet, with relatively high levels of ascorbic acid and fibre (Chedoloh, 2018). The VT pulps is also a fairly good source of minerals and antioxidants (Afolabi et al., 2018). Normally, chewy products in the market in Thailand use non-halal gelatin, which is either from leather or pork bones. They are derived from collagen that comprises about 25 to $35 \%$ of total body protein, through thermal hydrolysis (Vijayaraghavan et al., 2009; Tabarestani et al., 2010). The development of new products from VT in various forms in the three southern border provinces is an important economic. One of the choices of the product's development was chewy products that are unique in consumption. In this study, the amount of halal gelatin content and the production process on physical-chemical, sensory acceptance and antioxidant were determined.

\section{Materials and methods}

\subsection{Procurement of raw materials and chemicals}

Chewy food production using sugar, glucose syrup, salt, cassava flour, brass pan, stainless steel tray, silicone mould, and refrigerator were obtained from the Yala market, Thailand. While, dried velvet tamarind from the Hamidah establishment, Yarang district, Pattani province. The TV has been stored for approximately one year. Next, the fish gelatin was obtained from Halamic Company International (Thailand). The strength of the gelatin was 247 Bloom grams; $\mathrm{pH}$ was 5.6, moisture content was $11.1 \%$ and proteins more than was $86.5 \%$; respectively. The Folin-Ciocalteu reagent and all other chemicals used in this study were of analytical grade and supplied by Sigma Chemical Co. The spectrophotometric measurements were performed on UV/Vis spectrophotometer (Libra S32 PC, Biochrom Ltd., Cambridge, UK)

\subsection{Preparation of VT}

The shells and seeds of dried VT fruits were removed manually by hand. Then the selection of raw material of quality dried VT was made for the next process. In a typical experiment, the quality dried VT $(100 \mathrm{~g})$ was mixed with water in the ratio of $1: 2(\mathrm{D} / \mathrm{W})$. They were homogenized by a hand-held blender (SHARP\#EM-11, Japan). It was kept at the bottom of the VT solution for further study.

\subsection{Gelatin on chewy of VT}

The formulation of chewy product development consists of $300 \mathrm{~g}$ of VT, $230 \mathrm{~g}$ of sugar, $100 \mathrm{~g}$ of glucose syrup, $80 \mathrm{~g}$ of cassava flour and $2 \mathrm{~g}$ of salt (Table 1). It was divided into 6 formulations which include different levels of gelatin with $1.5,3,4.5,6,7.5$, and $9 \%(\mathrm{w} / \mathrm{w})$. Each formulation was placed and stirred for 5 minutes in the brass pan at low temperature until mixed well. The product was put in a silicone mould with a hole size of about $0.5 \mathrm{~cm}$ depth, approximately $1 \mathrm{~cm}$ long, and then place in a large plastic bag to prevent contamination. The chewy product was refrigerated at a temperature of about $4-5^{\circ} \mathrm{C}$ for $4 \mathrm{hrs}$ until setting chewy was formed. Next, the product was taken out of the silicone mould and put in the PP plastic bag.

\subsection{Processing method of chewy of VT}

The factor in VT ratio solution (sugar: VT solution) and the preparation of VT solution (FVT and UVT) affected the physical-chemical and sensory evaluation. VT solution of 200, 300 and $400 \mathrm{~g}$, with two methods process, were FVT and UVT. Ingredient weighing $230 \mathrm{~g}$ of sugar, $100 \mathrm{~g}$ of glucose syrup, $2 \mathrm{~g}$ of salt, and $60 \mathrm{~g}$ of gelatin (Table 2) were added into brass pan and was low heated. The mix solution was stirred for about 5 mins until the mixture dissolved well and became a chewy product. Next, the product was put in a silicone mould with a hole size of about $0.5 \mathrm{~cm}$ deep.

\subsection{Chemical-physical properties}

The chewy VT products were analysed for their chemical-physical properties. Colour was analysed as the physical properties of the VT products. The colour of each type of VT sample was evaluated by measuring $L^{*}$,

Table 1 .Ingredients of using gelatin in the production of the chewy product

\begin{tabular}{lcccccc}
\hline & \multicolumn{5}{c}{ Ingredients quantity (grams) } \\
\cline { 2 - 7 } \multicolumn{1}{c}{ Ingredients } & Gelatin & Gelatin & Gelatin & Gelatin & Gelatin & Gelatin \\
& $1.5 \%$ & $3.0 \%$ & $4.5 \%$ & $6.0 \%$ & $7.5 \%$ & $9.0 \%$ \\
\hline VT solution (g) & 300 & 300 & 300 & 300 & 300 & 300 \\
Sugar (g) & 230 & 230 & 230 & 230 & 230 & 230 \\
Salt (g) & 2 & 2 & 2 & 2 & 2 & 2 \\
Glucose syrup (g) & 100 & 100 & 100 & 100 & 100 & 100 \\
Cassava flour(g) & 80 & 80 & 80 & 80 & 80 & 80 \\
\hline
\end{tabular}


Table 2. The FVT and UVT formula design for chewy products

\begin{tabular}{lcccccc}
\hline \multirow{2}{*}{ Ingredients } & \multicolumn{3}{c}{ FVT } & \multicolumn{3}{c}{ UVT } \\
\cline { 2 - 7 } & $1: 0.87$ & $1: 1.30$ & $1: 1.74$ & $1: 0.87$ & $1: 1.30$ & $1: 1.74$ \\
\hline VT solution (g) & 200 & 300 & 400 & 200 & 300 & 400 \\
Sugar (g) & 230 & 230 & 230 & 230 & 230 & 230 \\
Salt (g) & 2 & 2 & 2 & 2 & 2 & 2 \\
Glucose syrup (g) & 100 & 100 & 100 & 100 & 100 & 100 \\
Cassava flour (g) & 80 & 80 & 80 & 80 & 80 & 80 \\
Fish gelatin (g) & 60 & 60 & 60 & 60 & 60 & 60 \\
\hline
\end{tabular}

$a^{*}, b^{*}$ parameters using a reflectance colourimeter. The colour was expressed in CIE-Lab parameters as $L^{*}$ (whiteness/darkness), $a^{*}$ (redness/greenness) and $b^{*}$ (yellow/blue). Meanwhile, the $\mathrm{pH}$ measurement, TSS, and vitamin $\mathrm{C}$ were analysed as the chemical properties of the VT products. All methods were analysed gravimetrically following the AOAC method (2000).

\subsection{DPPH radical scavenging activity}

The radical scavenging ability of chewy product extract was determined using the stable radical 2, 2diphenyl-1-picrylhydrazyl (DPPH) according to the methodology done by Shahidi et al. (1992). The reaction mixture containing $1.5 \mathrm{~mL}$ of a DPPH methanolic solution $(0.15 \mathrm{mM})$ and $0.5 \mathrm{mg} / \mathrm{mL}$ of the crude extract (methanol for the control) was incubated at $37^{\circ} \mathrm{C}$ for 30 min, and the absorbance was measured at $517 \mathrm{~nm}$. Spectrophotometrically. The per cent of DPPH discolouration of the sample was then calculated. Gallic acid standard $(10 \mu \mathrm{g} / \mathrm{mL})$ was used as a positive control. $\mathrm{IC}_{50}$ was calculated from $\%$ inhibition. The control solution was prepared by mixing ethanol $(1.5 \mathrm{~mL})$ and DPPH radical solution $(1.5 \mathrm{~mL})$. Ascorbic acid and methanol were as a reference standard and blank, respectively. The DPPH scavenging activity percentage was determined according to equation:

$\%$ inhibition $=[($ A control - A sample $) /($ A control $)]$ $\times 100$

Where A control = absorbance of DPPH alone and A sample $=$ absorbance of DPPH along with different concentrations of extracts

\subsection{Total phenolic content}

The Folin-Ciocalteu assay was used to determine the total phenolic content (TPC) of the chewy product extract according to the methodology of Piljac et al. (2009) using gallic acid (GA) as the standard. The TPC was expressed as $\mathrm{mg}$ gallic acid equivalent/g sample. The absorbance of the sample, as well as the absorbance of the gallic acid standard, were determined at $760 \mathrm{~nm}$ against the blank. The final result was from three absorbance readings for each averaged and taken sample.

\subsection{Sensory evaluation}

Sensory testing was performed in Yala Rajabhat
University Sensory Laboratory. 50 non-trained panellists were selected to equally represent genders with equal representation of inside age categories (18-45). Panellists were asked effective questions, including questions on colour, flavour, taste, texture, chewiness, sweetness, salty, sourness, and overall linking. Questions were done using a 9-point hedonic scale, with 1 corresponding with dislike extremely and 9 with like extremely (Meilgaard et al., 1990).

\subsection{Statistical analysis}

Statistical analysis was done followed by a Completely Randomised Design (CRD) for physical and chemical properties (conducting three trials). Meanwhile, the Randomised Complete Block Design (RCBD) was done for the Sensory test. A linear mixed model with treatments (sugar and VT solution). A mixed model in Statistical Package for the Social Sciences (SPSS) software is employed. Duncan's new multiple range test (DMRT) tests were used for comparison of means of treatments when statistical significance is at $p \leq 0.05$.

\section{Results and discussion}

\subsection{Effect of halal gelatin on sensory evaluation}

In this study, the gelatin content in chewy products was used as $1.5,3,4.5,6,7.5$ and $9 \% \mathrm{w} / \mathrm{w}$. The results showed that gelatin increased the effect of the sensory acceptance of the characteristics of colour, taste, texture, chewiness, sweetness, sourness and overall linking significantly different $(p \leq 0.05)$. In contrast, the flavour and salty characteristics were not different. $(p>0.05)$. Chewy products with $9 \%$ of gelatin gave the highest overall likeness score of 7.23 (moderate preference) as evaluated by a sensory panel. (Table 3 ). Typically, the gelatin is used in food products, with a concentration of the gelling agent at $1-5 \%$ (Tosh et al., 2003).In this study, $9 \%$ of gelatin was used from products with high acidity of approximately 3.00-3.50 (Chedoloh, 2018). Increasing gelatin content could enhance the product sweet taste may be related to glutamic acid in gelatin (Jamilah and Harvinder, 2020). Thus, product processing used low temperatures to protect the product's nutritional value from losing or denature nutrition. (Igwemmar et al., 2013). Gelatin melts at a much lower temperature because the junction zones are only bound by weak 
Table 3. Results of sensory test of chewy of VT products

\begin{tabular}{lcccccc}
\hline \multirow{2}{*}{ Attributes } & \multicolumn{5}{c}{ Gelatin content in chewy production } \\
\cline { 2 - 7 } & $1.50 \%$ & $3.00 \%$ & $4.50 \%$ & $6.00 \%$ & $7.50 \%$ & $9.00 \%$ \\
\hline Colour & $5.62 \pm 1.32^{\mathrm{d}}$ & $6.09 \pm 1.18^{\mathrm{c}}$ & $6.19 \pm 0.96^{\mathrm{bc}}$ & $6.34 \pm 1.15^{\mathrm{abc}}$ & $6.66 \pm 1.10^{\mathrm{ab}}$ & $6.82 \pm 1.00^{\mathrm{a}}$ \\
Flavour ${ }^{*} \mathrm{~ns}$ & $5.98 \pm 1.00$ & $6.00 \pm 1.02$ & $6.08 \pm 1.28$ & $6.20 \pm 0.67$ & $6.16 \pm 0.91$ & $6.29 \pm 1.05$ \\
Taste & $5.85 \pm 1.20^{\mathrm{b}}$ & $6.10 \pm 1.31^{\mathrm{ab}}$ & $6.20 \pm 1.54^{\mathrm{ab}}$ & $6.28 \pm 1.14^{\mathrm{ab}}$ & $6.45 \pm 1.14^{\mathrm{a}}$ & $6.65 \pm 0.96^{\mathrm{a}}$ \\
Texture & $6.28 \pm 1.28^{\mathrm{b}}$ & $6.34 \pm 1.06^{\mathrm{b}}$ & $6.43 \pm 0.78^{\mathrm{b}}$ & $6.43 \pm 0.71^{\mathrm{b}}$ & $6.30 \pm 0.95^{\mathrm{b}}$ & $6.88 \pm 0.89^{\mathrm{a}}$ \\
Chewiness & $5.81 \pm 1.10^{\mathrm{c}}$ & $6.20 \pm 1.07^{\mathrm{bc}}$ & $6.30 \pm 1.10^{\mathrm{b}}$ & $6.27 \pm 0.89^{\mathrm{b}}$ & $6.62 \pm 0.95^{\mathrm{ab}}$ & $6.83 \pm 1.12^{\mathrm{a}}$ \\
Sweetness $^{\mathrm{a}}$ & $5.88 \pm 1.17^{\mathrm{c}}$ & $6.02 \pm 1.11^{\mathrm{c}}$ & $6.09 \pm 0.78^{\mathrm{c}}$ & $6.30 \pm 1.27^{\mathrm{ac}}$ & $6.64 \pm 1.31^{\mathrm{ab}}$ & $6.76 \pm 0.62^{\mathrm{a}}$ \\
Salty $^{*}{ }^{\mathrm{a}}$ & $6.50 \pm 0.89$ & $6.05 \pm 1.23$ & $6.25 \pm 0.97$ & $5.75 \pm 1.16$ & $6.00 \pm 1.08$ & $6.35 \pm 1.31$ \\
Sourness $^{\text {Overall linking }}$ & $5.78 \pm 1.25^{\mathrm{d}}$ & $6.04 \pm 1.08^{\mathrm{cd}}$ & $6.21 \pm 0.98^{\mathrm{cd}}$ & $6.46 \pm 1.16^{\mathrm{bc}}$ & $6.77 \pm 1.08^{\mathrm{ab}}$ & $7.00 \pm 1.14^{\mathrm{a}}$ \\
\hline
\end{tabular}

Values are presented as mean \pm SD. Values with different superscripts within the same row are significantly different ( $\leq \leq 0.05$ ). $*_{n s}$ is Non-significant differences $(\mathrm{p}>0.05)$.

hydrogen bonds (Saha and Bhattacharya, 2010). Taste perception occurs when water-soluble chemicals in the mouth contact the epithelial cells of the taste buds (Reed et al., 2006). The perception of the different taste qualities is mediated by diverse mechanisms that are located in the cells belonging to three functional classes. Specifically, the Heterodimer G-protein-coupled receptors (GPCRs) mediate the sweet and umami transduction (Jiang et al., 2004).

\subsection{Effect ratios and processes on sensory evaluation}

Product developments of chewy products were using the water mixed VT ratio at 1:2. The factors in the study were the ratio of sugar: VT solution was 1:0.87, 1:1.30, and 1:1.74. The results of the sensory evaluation of chewy products were presented in Table 4. The processes of production were FVT and UVT. The results revealed that ratios and processes affected the sensory evaluation. The panellist test scores accepted of colour, taste, texture, chewiness, sweetness, sourness and overall linking were significantly different $(p \leq 0.05)$. The difficulty of flavour and salty was not significantly different $(p>0.05)$. Sensory testing showed that the ratio of sugar: VT solution 1:1.74 gave the highest average preference score. The scores for overall liking (7.15) and taste (6.66) obtained for UVT of chewy were significantly higher than scores obtained for FVT of chewy (6.86 and 6.60, respectively). The preference of the colour of the UVT may be due to its high carotenoid content, which gives an attractive red or yellow colour that also contributes to food quality (Sharma et al., 2011). The taste and flavour of the chewy product may be due to a combination of high contents of tartaric acid and reducing sugars found in VT (Minh, 2015).

\subsection{Effect ratios and processes on physical-chemistry properties}

The physical-chemistry properties of processing showed in Table 5-6. Sample of the ratio of sugar: VT solution 1:0.87 had the highest value tending towards lightness/whiteness (41.11) than other samples. The treated samples have lower values in decreasing order of lightness/whiteness $\left(L^{*}\right)$ with a sample ratio of FVT1:1.30 (33.94), and 1:1.74 (35.41), respectively (Table 5). Similarly, samples of UVT have lower values in decreasing order of lightness/whiteness. The product characteristics showed that the chewy product became deeper in colour with the addition of VT (Figure 1). The $a^{*}$ values revealed an increase in redness with the addition of VT solution of VT pulp. At the same time, the $b^{*}$ had a decrease in the value of yellow.

Table 4 . The sensory evaluation results of each velvet tamarind chewy product.

\begin{tabular}{|c|c|c|c|c|c|c|}
\hline \multirow{2}{*}{ Attributes } & \multicolumn{3}{|c|}{ FVT } & \multicolumn{3}{|c|}{ UVT } \\
\hline & $1: 0.87$ & $1: 1.30$ & $1: 1.74$ & $1: 0.87$ & $1: 1.30$ & $1: 1.74$ \\
\hline$\overline{\text { Colour }}$ & $5.84 \pm 1.43^{b}$ & $6.43 \pm 1.11^{\mathrm{ab}}$ & $6.70 \pm 1.38^{\mathrm{a}}$ & $6.69 \pm 1.65^{\mathrm{a}}$ & $6.44 \pm 1.21^{\mathrm{ab}}$ & $7.04 \pm 1.95^{\mathrm{a}}$ \\
\hline Flavour ${ }^{* \text { ns }}$ & $5.98 \pm 1.06$ & $6.19 \pm 1.31$ & $6.32 \pm 1.15$ & $6.06 \pm 1.33$ & $6.06 \pm 1.05$ & $6.26 \pm 1.27$ \\
\hline Taste & $5.54 \pm 1.68^{\mathrm{b}}$ & $6.22 \pm 1.21^{\mathrm{a}}$ & $6.60 \pm 1.32^{\mathrm{a}}$ & $6.16 \pm 1.34^{\mathrm{a}}$ & $6.58 \pm 1.48^{\mathrm{a}}$ & $6.66 \pm 1.56^{\mathrm{a}}$ \\
\hline Texture & $5.89 \pm 1.75^{\mathrm{b}}$ & $6.41 \pm 1.28^{\mathrm{ab}}$ & $6.71 \pm 1.45^{\mathrm{a}}$ & $6.93 \pm 1.88^{\mathrm{a}}$ & $6.57 \pm 1.78^{\mathrm{ab}}$ & $6.15 \pm 1.61^{\mathrm{ab}}$ \\
\hline Chewiness & $5.91 \pm 1.43^{\mathrm{b}}$ & $6.42 \pm 1.42^{\mathrm{ab}}$ & $6.74 \pm 1.55^{\mathrm{a}}$ & $6.16 \pm 1.40^{\mathrm{ab}}$ & $6.83 \pm 1.13^{\mathrm{a}}$ & $6.61 \pm 1.43^{\mathrm{ab}}$ \\
\hline Sweetness & $6.35 \pm 1.07^{\mathrm{ab}}$ & $6.02 \pm 1.52^{\mathrm{b}}$ & $6.82 \pm 1.57^{\mathrm{a}}$ & $6.90 \pm 1.95^{\mathrm{a}}$ & $6.56 \pm 1.57^{\mathrm{ab}}$ & $6.75 \pm 1.41^{\mathrm{a}}$ \\
\hline Salty ${ }^{*} \mathrm{~ns}$ & $5.74 \pm 1.26$ & $5.69 \pm 1.32$ & $6.21 \pm 1.29$ & $5.77 \pm 1.26$ & $6.17 \pm 1.19$ & $6.20 \pm 1.21$ \\
\hline Sourness & $5.69 \pm 1.26^{\mathrm{c}}$ & $5.72 \pm 1.50^{\mathrm{c}}$ & $5.86 \pm 1.40^{\mathrm{ab}}$ & $6.41 \pm 1.79^{\mathrm{ab}}$ & $6.24 \pm 1.05^{\mathrm{ab}}$ & $6.88 \pm 1.78^{\mathrm{a}}$ \\
\hline Overall linking & $6.07 \pm 1.51^{\mathrm{c}}$ & $6.18 \pm 1.60^{b c}$ & $6.86 \pm 1.10^{\mathrm{ab}}$ & $6.75 \pm 1.01^{\mathrm{abc}}$ & $7.00 \pm 1.83^{\mathrm{a}}$ & $7.15 \pm 1.82^{\mathrm{a}}$ \\
\hline
\end{tabular}

Values are presented as mean \pm SD. Values with different superscripts within the same row are significantly different ( $\leq \leq 0.05$ ). $*_{n s}$ is Non-significant differences $(\mathrm{p}>0.05)$. 
Table 5. Physical characteristics of the chewy products

\begin{tabular}{ccccccc}
\hline \multirow{2}{*}{ Color } & \multicolumn{3}{c}{ FVT } & \multicolumn{3}{c}{ UVT } \\
\cline { 2 - 7 } & $1: 0.87$ & $1: 1.30$ & $1: 1.74$ & $1: 0.87$ & $1: 1.30$ & $1: 1.74$ \\
\hline$L^{*}$ & $41.11 \pm 1.25^{\mathrm{a}}$ & $33.94 \pm 1.13^{\mathrm{b}}$ & $35.41 \pm 0.56^{\mathrm{b}}$ & $22.77 \pm 1.04^{\mathrm{c}}$ & $21.02 \pm 1.30^{\mathrm{c}}$ & $13.82 \pm 0.04^{\mathrm{bd}}$ \\
$a^{*}$ & $1.28 \pm 0.12^{\mathrm{d}}$ & $1.95 \pm 0.27^{\mathrm{d}}$ & $3.04 \pm 0.20^{\mathrm{c}}$ & $6.36 \pm 0.21^{\mathrm{a}}$ & $3.57 \pm 0.18^{\mathrm{b}}$ & $3.02 \pm 0.09^{\mathrm{c}}$ \\
$b^{*}$ & $10.51 \pm 0.02^{\mathrm{a}}$ & $10.54 \pm 0.67^{\mathrm{a}}$ & $10.92 \pm 0.57^{\mathrm{a}}$ & $6.27 \pm 0.27^{\mathrm{b}}$ & $2.58 \pm 0.13^{\mathrm{c}}$ & $1.92 \pm 0.05^{\mathrm{c}}$ \\
\hline
\end{tabular}

Values are presented as mean \pm SD. Values with different superscripts within the same row are significantly different $(\mathrm{p} \leq 0.05)$. $*_{n s}$ is Non-significant differences $(\mathrm{p}>0.05)$.

Table 6. Chemical properties of the chewy products

\begin{tabular}{ccccccc}
\hline \multirow{2}{*}{ Parameters } & \multicolumn{3}{c}{ FVT } & \multicolumn{3}{c}{ UVT } \\
\cline { 2 - 7 } & $1: 0.87$ & $1: 1.30$ & $1: 1.74$ & $1: 0.87$ & $1: 1.30$ & $1: 1.74$ \\
\hline Moisture content (\%) & $9.99 \pm 1.44^{\mathrm{a}}$ & $10.40 \pm 1.28^{\mathrm{a}}$ & $11.33 \pm 1.15^{\mathrm{a}}$ & $7.04 \pm 2.33^{\mathrm{a}}$ & $5.77 \pm 1.43^{\mathrm{b}}$ & $4.96 \pm 1.02^{\mathrm{b}}$ \\
$\mathrm{a}_{\mathrm{w}}$ & $0.68 \pm 0.00^{\mathrm{c}}$ & $0.69 \pm 0.00^{\mathrm{b}}$ & $0.71 \pm 0.00^{\mathrm{a}}$ & $0.69 \pm 0.00^{\mathrm{b}}$ & $0.69 \pm 0.00^{\mathrm{b}}$ & $0.66 \pm 0.00^{\mathrm{d}}$ \\
pH & $4.21 \pm 0.01^{\mathrm{a}}$ & $3.98 \pm 0.01^{\mathrm{b}}$ & $3.98 \pm 0.01^{\mathrm{b}}$ & $3.98 \pm 0.01^{\mathrm{b}}$ & $3.83 \pm 0.01^{\mathrm{b}}$ & $3.65 \pm 0.01^{\mathrm{c}}$ \\
TSS ( ${ }^{(}$Brix) & $5.80 \pm 0.10^{\mathrm{c}}$ & $6.53 \pm 0.32^{\mathrm{b}}$ & $7.77 \pm 0.35^{\mathrm{a}}$ & $5.90 \pm 0.10^{\mathrm{c}}$ & $4.67 \pm 0.31^{\mathrm{d}}$ & $4.40 \pm 0.10^{\mathrm{d}}$ \\
\hline
\end{tabular}

Values are presented as mean \pm SD. Values with different superscripts within the same row are significantly different $(\mathrm{p} \leq 0.05)$. *ns is Non-significant differences $(\mathrm{p}>0.05)$.

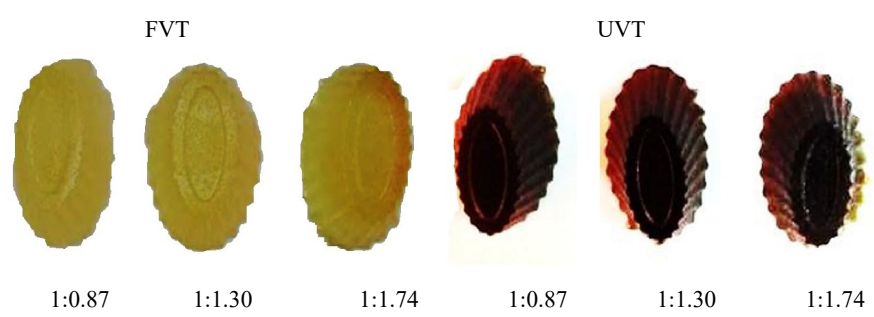

Figure 1. Processing method of velvet tamarind chewy product of FVT and UVT.

The composition of the chemical properties of the chewy product is shown in Table 6 . The ratio solution (sugar: VT solution) and preparation of VT solution FVT and UVT had different effects on moisture content $(p \leq 0.05)$, where the FVT had higher moisture content than UVT chewy products significantly different. $(p \leq 0.05)$. The moisture content was in the percentage range of 9.99-11.33 and 4.96-7.04, respectively (Table 6 ). This result corresponded to the $a_{w}$ value of chewy products from FVT and UVT. Lower moisture and $\mathrm{a}_{\mathrm{w}}$ content was desirable in flour as this chews the storability of the product and prevents susceptibility to microbial attack (Abiodun et al., 2017). The value for $\mathrm{pH}$ in the chewy product of the UVT was $\mathrm{pH} 3.65-3.98$, in which the $\mathrm{pH}$ value was less than FVT (pH 3.98-4.21). The $\mathrm{pH}$ value indicates that the product was acidic. Chedoloh (2018) reported that $\mathrm{pH}$ values for the pulp of VT were $\mathrm{pH}$ 2.83-2.98.

The total soluble solids (TSS) increased in FVT significantly $(p \leq 0.05)$. While UVT was TSS decreased $(p \leq 0.05)$. The TSS of the chewy product were 5.80-7.77 $\mathrm{Bx}$ (FVT) and $4.40-5.90^{\circ} \mathrm{Bx}$ (UVT). The highest amount of TSS was found in chewy of UVT (ratio 1:0.87), 5.90 $\mathrm{Bx}$ and the highest in FVT (ratio 1:1.74), $7.77^{\circ} \mathrm{Bx}$. Generally higher TSS indicates more sugar in the pulp of VT. The riper the fruits, the more amount of sugar in fruits (Haque et al., 2009).

\subsection{Effect ratios and processes on antioxidant}

The chewy product shows higher DPPH radical scavenging activity compared to the unripe sample. As shown in Table 7 , there was a significant difference $(p \leq 0.05)$ in the $\mathrm{IC}_{50}$ of the ratio solution (sugar: VT solution) and the preparation of VT solution FVT and UVT of chewy product. The results showed that $\mathrm{IC}_{50}$ range 89.11-109.46 $\mu \mathrm{g} / \mathrm{mL}$ (FVT) and 53.64-73.64 $\mu \mathrm{g} /$ $\mathrm{mL}$ (UVT), respectively (Table 7). DPPH was used as a free radical to evaluate the antioxidative activity of some natural sources, and the degree of its discolouration was attributed to the hydrogen donating ability of test compounds which was indicative of their scavenging potential (Shimada et al., 1992). This scavenging activity of tamarind pulp may be related to their presence of flavonoids, condensed tannin, and polyphenols thus contributing to their electron transfer/hydrogen donating ability (Haque et al., 2009).

The TPC was the highest for the chewy product. As shown in TPC in Table 7, there was a significant difference $(p \leq 0.05)$. TPC analysis of the ratio solution (sugar: VT solution) and the preparation of FVT and UVT showed that ratio 1:1.74 of UVT had the highest TPC at $163.21 \pm 0.02 \mathrm{mg} \mathrm{GAE} / \mathrm{g}$ sample (Table 7). Total phenolic compounds were composed of phenol and polyphenols. The initial raw material, preparation, and production process affected increasing the phenolic compounds, including further quinone formation in velvet tamarind fruit (Obulesu and Bhattacharya, 2011).

Antioxidants increase the shelf life of foods by preventing the oxidation of nutrients (Reddy et al., 2005). The phenolic compounds possess different biomedical properties such as antiallergenic, antiinflammatory and antiviral. Moreover, it reduces risks 
Table 7. The results of antioxidant of each chewy product

\begin{tabular}{lcccccc}
\hline \multirow{2}{*}{ Parameters } & \multicolumn{3}{c}{ FVT } & \multicolumn{3}{c}{ UVT } \\
\cline { 2 - 7 } & $1: 0.87$ & $1: 1.30$ & $1: 1.74$ & $1: 0.87$ & $1: 1.30$ & $1: 1.74$ \\
\hline Vitamin C $(\mathrm{mg} / 100 \mathrm{~mL})^{*} 0.96 \pm 0.21^{\mathrm{f}}$ & $3.27 \pm 0.12^{\mathrm{e}}$ & $6.22 \pm 0.56^{\mathrm{d}}$ & $6.53 \pm 0.19^{\mathrm{c}}$ & $8.29 \pm 0.63^{\mathrm{b}}$ & $10.99 \pm 0.37^{\mathrm{a}}$ \\
DPPH assay IC $50(\mu \mathrm{g} / \mathrm{mL})$ & $109.46 \pm 7.80^{\mathrm{a}}$ & $96.37 \pm 1.96^{\mathrm{b}}$ & $89.11 \pm 4.54^{\mathrm{b}}$ & $73.64 \pm 4.16^{\mathrm{c}}$ & $64.64 \pm 1.25^{\mathrm{d}}$ & $53.64 \pm 0.95^{\mathrm{e}}$ \\
TPC $(\mathrm{mg} \mathrm{GAE} / \mathrm{g} \mathrm{sample})$ & $7.94 \pm 0.42^{\mathrm{f}}$ & $42.06 \pm 0.01^{\mathrm{e}}$ & $130.52 \pm 0.02^{\mathrm{b}}$ & $67.06 \pm 0.04^{\mathrm{d}}$ & $74.75 \pm 0.05^{\mathrm{c}}$ & $163.21 \pm 0.02^{\mathrm{a}}$ \\
\hline
\end{tabular}

Values are presented as mean \pm SD. Values with different superscripts within the same row are significantly different ( $\mathrm{p} \leq 0.05)$. $*_{\mathrm{n}}$ is Non-significant differences $(\mathrm{p}>0.05)$.

against cancer, cataract, and coronary health problems including hypertension (Priya et al., 2008). Polyphenolic contents of the chewy product function as good donors of electron and hydrogen atoms, and therefore, were capable of terminating radical chain reaction by converting free radicals and reactive oxygen species to more stable products. The degree of discolouration indicates the scavenging potentials of the antioxidant extract (Obulesu and Bhattacharya, 2011).

The vitamin C composition of chewy products developed from the analysis of the ratio solution (sugar: VT solution) and the preparation of VT solution FVT and UVT was presented in Table 7 with significantly different $(p \leq 0.05)$. The vitamin $\mathrm{C}$ level of product UVT was $6.53-10.99 \mathrm{mg} / 100 \mathrm{~g}$ higher than FVT at 0.96-6.22 $\mathrm{mg} / 100 \mathrm{~g}$ (Table 7). The high vitamin $\mathrm{C}$ value obtained from the increased VT makes it a vital health product. Vitamin $\mathrm{C}$ is reduced by heating because it is not resistant to heat, especially if the container does not have a cover and cooking takes a long time (Richardson et al., 2004).

\section{Conclusion}

The study showed that chewy products of VT contained a substantial amount of vitamin $\mathrm{C}$, antioxidant and TPC. The use of gelatin and process variables to produce the chewy product to customise the evaluation was recognised by a sensory panel (7.15 score; like moderately). However, the product must be developed to maintain product texture, increase acidity and reduce the moisture content to make the product quality product.

\section{Conflict of interest}

The authors declare no conflict of interest.

\section{Acknowledgements}

The authors are grateful for the research funding from The National Research Council of Thailand (NRCT) and the Thailand Research Fund (TRF) and also the support Faculty of Science, Technology and Agriculture of Yala Rajabhat University.

\section{References}

Abiodun, O.A., Dauda, A.O., Adebisi, T.T. and Alonge, C.D. (2017). Physico-chemical, microbial and sensory properties of kunu zaki beverage sweetened with black velvet tamarind (Dialium guineense). Croatian Journal of Food Science and Technology, 9(1), 46-56. https://doi.org/ 10.17508/ CJFST.2017.9.1.07

AOAC. (2000). Official methods of analysis of the association of official chemists. $17^{\text {th }}$ ed. Washinton DC, USA: The Association of Official Analytical Chemists Inc.

Chedoloh, R. (2018). Study on post-harvest management of fresh black velvet tamarind and dehydrating methods on the properties and sensory evaluation of pre-processed product. Rajamangala University of Technology Srivijaya Research Journal, 10(1), 5264.

Chedoloh, R. and Chemalee, S. (2019). Effect of hydrocolloids on quality and stability of halal velvet tamarind jelly during storage. RMUTI Journal Science and Technology, 12(2), 62-74.

Figiel, A. and Tajner-Czopek, A. (2006). The effect of candy moisture content on texture. Journal of Foodservice, 17(1), 189-195. https:// doi.org/10.1111/j.1745-4506.2006.00037.x

Haque, M.N., Saha, B.K., Karim, M.R. and Bhuiyan, M.N.H. (2009). Evaluation of nutritional and physico-chemical properties of several selected fruits in Bangladesh. Bangladesh Journal of Scientific and Industrial Research, 44(3), 353-358. https:// doi.org/10.3329/bjsir.v44i3.4410

Igwemmar, N.C., Kolawole, S.A. and Imran, I.A. (2013). Effect of heating on vitamin $\mathrm{C}$ content of some selected vegetables. International Journal of Scientific and Technology Research, 2(11), 209-212.

Jamilah, B. and Harvinder, K.G. (2002). Properties of gelatins from skins of fish-black tilapia (Oreochromis mossambicus) and red tilapia (Oreochromis nilotica). Food Chemistry, 77(1), 8184. https://doi.org/10.1016/S0308-8146(01)00328-4

Jiang, P., Ji, Q., Liu, Z., Snyder, L.A., Benard, L.M., Margolskee, R.F. and Max, M. (2004). The cysteinerich region of T1R3 determines responses to 
intensely sweet proteins. Journal of Biological Chemistry, 279(43), 45068-45075. https:// doi.org/10.1074/jbc.M406779200

Meilgaard, M., Civille, G.V. and Carr, B.T. (1999). Sensory Evaluation Techniques. $3^{\text {rd }}$ ed. New York, USA: CRC. https://doi.org/10.1201/9781003040729

Minh, N.P. (2015). Different factors affecting tamarind beverage production. Bulletin of Environment, Pharmacology and Life Sciences, 4(7), 36-40.

Obulesu, M. and Bhattacharya, S. (2011). Color changes of tamarind (Tamarindus indica L.) pulp during fruit development, ripening, and storage. International Journal of Food Properties, 14(3), 538-549. https:// doi.org/10.1080/10942910903262129

Office of the Board of Investment. (2016). Thailand: food industry. Bangkok, Thailand: Office of the Board of Investment.

Piljac, J., Martinez, S., Valek, L., Stipčević, T. and Kovačević Ganić, K. (2005). A comparison of methods used to define the phenolic content and antioxidant activity of Croatian wines. Food Technology and Biotechnology, 43(3), 271-276.

Priya, T.T., Sabu, M.C. and Jolly, C.I. (2008). Free radical scavenging and anti-inflammatory properties of Lagerstroemia speciosa (L). Inflammopharmacology, 16(4), 182-187. https:// doi.org/10.1007/s10787-008-7002-6

Priyakorn, P. (2017). Halal Standards and Certification Systems in Thailand. Bangkok, Thailand. 16 May 2017.

Reddy, V., Urooj, A. and Kumar, A. (2005). Evaluation of antioxidant activity of some plant extracts and their application in biscuits. Food Chemistry, 90(12), 317-321. https://doi.org/10.1016/ j.foodchem.2004.05.038

Reed, D.R., Tanaka, T. and McDaniel, A.H. (2006). Diverse tastes: Genetics of sweet and bitter perception. Physiology and Behavior, 88(3), 215226. https://doi.org/10.1016/j.physbeh.2006.05.033

Reuters, T. and Standard, D. (2018). State of the global Islamic economy report 2016/17. Dubai: Thomson Reuters.

Richardson, A.C., Marsh, K.B., Boldingh, H.L., Pickering, A.H., Bulley, S.M., Frearson, N.J. and Macrae, E.A. (2004). High growing temperatures reduce fruit carbohydrate and vitamin $\mathrm{C}$ in kiwifruit. Plant, Cell and Environment, 27(4), 423$435 . \quad$ https://doi.org/10.1111/j.13653040.2003.01161.x

Ruslan, A.A.A., Kamarulzaman, N.H. and Sanny, M. (2018). Muslim consumers' awareness and perception of Halal food fraud. International Food
Research Journal, 25(Suppl. 1), S87-S96.

Sadler, M. and Stowell, J.D. (2012). Calorie control and weight management. In O'Donnell, K. and Kearsley, M.W. (Eds.), Sweeteners and sugar alternatives in food technology, p. 77-90. Oxford, United Kingdom: Wiley-Blackwell. doi.org/10.1002/9781118373941.ch4

https://

Saha, D. and Bhattacharya, S. (2010). Hydrocolloids as thickening and gelling agents in food: a critical review. Journal of Food Science and Technology, 47 (6), 587-597. https://doi.org/10.1007/s13197-010$0162-6$

Sentko, A. and Willibald-Ettle, I. (2012). Isomalt. In O'Donnell, K. and Kearsley, M.W. (Eds.), Sweeteners and sugar alternatives in food technology, p. 243-273. Oxford, United Kingdom: Wiley-Blackwell. doi.org/10.1002/9781118373941.ch11

Sharma, S.K., Anup, G.A., Radhakrishman, L., Thapa, I., Shrestha, N.R., Pandel, N., Gurung, K., Maskey, R., Budathoki, A., Barai, N. and David, B.D. (2011). Prevalence of hypertension, obesity diabetes and metabolic syndrome in Nepal. International Journal of Hypertension, 2011, 821971. https:// doi.org/10.4061/2011/821971

Shimada, K., Fujikawa, K., Yahara, R. and Nakamura, T. (1992). Antioxidative properties of xanthan on autoxidation of soybean oil in American science. Journal of Agricultural and Food Chemistry, 40(6), 945-948. https://doi.org/10.1021/jf00018a005

Tabarestani, H.S., Maghsoudlou, Y., Motamedzadegan, A. and Mahoonak, A.S. (2010). Optimisation of physico-chemical properties of gelatin extracted from fish skin of rainbow trout (Onchorhynchus mykiss). Bioresource Technology, 101(15), 62076214. https://doi.org/10.1016/j.biortech.2010.02.071

Tosh, S.M., Marangoni, A.G., Hallett, F.R. and Britt, I.J. (2003). Aging dynamics in gelatin gel microstructure. Food Hydrocolloids, 17(4), 503-513. https://doi.org/10.1016/S0268-005X(03)00018-3

Vijayaraghavan, R., Thompson, B.C., MacFarlane, D.R., Kumar, R., Surianarayanan, M., Aishwarya, S. and Sehgal, P.K. (2009). Biocompatibility of choline salts as crosslinking agents for collagen based biomaterials. Chemical Communications, 46(2), 294296. https://doi.org/10.1039/B910601D 